\section{The Analysis of Barriers in Succession Processes of Family Business with the Use of Grey Incidence Analysis (Polish Perspective)}

\author{
Ewa Więcek-Janka \\ Poznan University of Technology, Poznan, Poland \\ ewa.wiecek-janka@put.poznan.pl \\ Rafał Mierzwiak \\ Poznan University of Technology, Poznan, Poland \\ rafal.mierzwiak@put.poznan.pl

\section{Joanna Kijewska} \\ Poznan University of Technology, Poznan, Poland \\ joanna.kijewska@put.poznan.pl
}

\begin{abstract}
The article presents results of research on the identification and evaluation of barriers faced by successors in family businesses during the first process of succession. The analysis of empirical material used grey systems theory, which was considered as an equivalent for the analysis of small samples and qualitative research. While conducting the literature review and empirical study, the authors concentrated on (a) the identification of barriers in the development of family firms and (b) eliciting the perspective of the new generation of owners in family firms entering the succession process through an empirical analysis of the assessed level of risk in relationships with family and business.
\end{abstract}

Keywords: Family business, grey incidence analysis, grey system theory

\section{Introduction}

Succession in a family firm can be discussed in various contexts-namely, as an act finalizing the period of management of one generation, without which it is difficult to define a company as a family business (Barach \& Ganitsky, 1995; Ganitsky, Carson, \& Doochin, 1988; Litz, 1995; Sharma, 2002; Ward, 1987); as a process that accompanies the owners and successors during the generation change (Astrachan \& Kolenko, 1994; Astrachan \& Shanker, 2003; Blake \& Saleh, 1995; Budge \& Janoff, 1991; Cadieux, Lorrain, \& Hugron, 2002; Danco, 1975; Davis, 1982; Klein 2000; Duh, 2003; Duh, Belak, \& Milferner, 2010; Dyer, 2006; Dyer, 2003; Letonja \& Duh, 2015); and as a systemic challenge that changes the view on the components of a family firms, redefines the norms and values, and influences business and family relations (Więcek-Janka, 2013). While discussing succession, one ought to look at a family firm as a system. The main challenge for explicitly defining the notions of family enterprise or family firm is the difficulty in the proper conceptualization of the level of component dependency,
ORIGINAL SCIENTIFIC PAPER

RECEIVED: FEBRUARY 2016

REVISED: APRIL 2016

ACCEPTED: MAY 2016

DOI: 10.1515/ngoe-2016-0010

UDK: 334.722 .24

JEL: D64, L26, M12

Citation: Więcek-Janka, E., Mierzwiak, R., \& Kijewska, J. (2016). The Analysis of Barriers in Succession Processes of Family Business with the Use of Grey Incidence Analysis (Polish Perspective). Naše gospodarstvo/Our Economy, 62(2), 33-41. DOI: 10.1515/ngoe-2016-0010

\section{NG OE}

NAŠE GOSPODARSTVO OUR ECONOMY

\begin{tabular}{l|l|l} 
Vol. 62 No. 2 & 2016 \\
\hline
\end{tabular}

pp. 33-41 
which is its immanent feature. Kepner (1991) considered that the strands of the family and business system are so tightly intertwined that it is impossible to disentangle them without seriously damaging one of them. Budge and Janoff (1991) conducted research to explain how business families draw from two discourses - the family and the business - to communicate and to understand themselves and the world. Similar research was conducted by Swagger (1991) who, studying the succession process in family firms, was analyzing the pattern of relationships among all the members of the generation of successors - namely, sons and daughters, including their spouses. He was interested in the influence of the relationships among the members of the next generation and their personal needs. In these approaches, the functioning spheres of the individuals, family, and business are combined within the framework of the concept of multigenerationality. The aforementioned fields (strands and discourses) are governed by different rules, needs, and values. Part of them function in co-existence, and some of them generate the effect of positive synergy; yet some have a negative influence. Maintaining a relative balance between fields defined in this manner forces the owners to engage in constant activity in order to merge the interests of these fields and redefine the values and order governing them. For the needs of this article, the authors adopted a definition that takes this division into account. Thus, a family enterprise is defined as:

a market organism trigonal in its structure, encompassing family, business and individuals, which functions according to various, but mutually adapted objectives, and which devotes its energy to accomplishing them in multigenerational perspective by management and the control over its functioning and ownership (Więcek-Janka, 2013, p. 35).

Many researchers and practitioners in the circle of family entrepreneurship have expressed the opinion that the responsibility for ensuring succession rests chiefly on the founders and owners of these firms (Danco, 1975). The remaining ones relate to the success of the succession process with the traits, competencies, and experiences of the subsequent generations (Barnes, 1988; Aldrich \& Cliff, 2003; Handler \& Kram, 1989; Dunk, Jimenez, Sarotar Zizek, Milfelner \& Kallus, 2015). The scientific papers also include a view that succession depends on family values and upbringing models employed by the parents (Arnoff, McClure, \& Ward, 2012; Davis, 1982; Handler \& Kram, 1989; Kedmenec, Sebjan, \& Tomic, 2015). Lansberg (1988) treated the succession process as "a change which influences the functioning the whole system of family and business, including the family members, and the environment meant as the suppliers, customers and local economy” (p. 120). The authors of the article acknowledge a similar approach to succession and treat succession as a planned change (Letonja \& Duh, 2015;
Więcek-Janka, 2013). A planned change can help impede conflicts and secure the relationships within the family, especially considering that succession process usually involves resistance-first at the planning level and later in the realization itself-which concerns the founders themselves (the seniors), the successor, the remaining members of the family, and finally non-family employees. Family enterprises frequently postpone the decision about entering the succession process in order to avoid problems and conflicts that can be related to it.

In the context of multigenerationality, one ought to strive for the recognition of succession as a systematic change, accomplished at the pre-assumed period of time, such as every 25 years (with the assumption of a family firm's proper course of development). Hence, what can the planned and systematic successional change be linked with, apart from the time frames? It can consist in a deliberate and organized search for and shaping of the opportunities to accomplish the objectives concerning upbringing and education, oriented toward preparing first the successor, second the senior to assume a new social role, and third the environment to accept the new (Duh et al., 2010; Więcek-Janka, 2011).

The aim of this article is to identify and analyze the barriers that may emerge in the succession process, especially barriers concerning the successors themselves. While conducting the literature review and empirical study, the authors concentrated on (a) the identification of barriers in the development of family firms and (b) the elicitation of the perspective of the new generation of owners in family firms entering the succession process, through an empirical analysis of the assessed level of risk of encountering the identified barriers in their personal succession-related experiences.

Due to the complex characteristics of barriers' identification in the functioning of family firms, especially succession, the accomplished studies ought to be treated not as responses to detailed questions, but as a complementary situational study, drawing from the experiences of the experts, including the founders of the companies, as well as the successors from the next generation.

\section{Description of the Collected Empirical Material}

The study was conducted in two stages, employing two research methods: an in-depth group interview and a survey. The objective of the first stage was the identification of the barriers in the succession process, based on the opinion of the successors in Polish family firms according to their responses during in-depth group interviews. The results of 
the conducted survey allowed for the classification of the barriers in the succession process into two groups: internal and external ones. Internal barriers are related to personal traits comprising knowledge, competencies, and personality, while the external ones encompass market conditions, culture along with family and business values, and finally interpersonal relationships. The model of successors' barriers in the succession process, taking their source into account, is presented in Table 1.

The study of Polish successors was conducted using an elaborate methodology whose chief objective was to elicit the subjectively identified barriers in the succession process. The statements had open characteristics and were obtained during two in-depth group interviews with successors entering the succession process $(n=25)$. In a survey led by a moderator, the interviewees presented their experiences related to the process of succession and the emotions associated with it. In one of the stages of the interview, the respondents were asked to name several (between 3 and 5) barriers that, in their opinion, impede the succession process. The obtained list of barriers is presented in Table 2 .
In the surveyed sample, fear was identified as a significant barrier. During the interview, the analysis of this category was deepened. As it turned out, fear in the succession process can be interpreted differently and can have different backgrounds. Hence, fear was divided into several different categories: fear of responsibility, fear of criticism, fear of competition, and fear of being unsuccessful.

In the second stage of the study, the successors themselves assessed the impact that the identified successors' barriers have. The test group consisted of successors of Polish family firms in the course of the succession process $(n=25)$. The identified barriers $\left(\mathrm{X}_{1}-\mathrm{X}_{19}\right)$ were included in the questionnaire and submitted for assessment in a five-point scale, where the influence of the identified barriers on the successor was rated as 1 (has no influence), 2 (has little influence), 3 (has a moderate influence), 4 (has a rather large influence), or 5 (has considerable influence). The following symbols were used: $\mathrm{X}_{1}=$ lack of professional training; $\mathrm{X}_{2}=$ lack of experience; $X_{3}=$ bad relations with parents; $X_{4}=$ other plans; $\mathrm{X}_{5}=$ successor is too young; $\mathrm{X}_{6}=$ large number of successors; $\mathrm{X}_{7}=$ lack of perspectives for development of the

Table 1. Barriers to Successors, Identified by Experts from Foreign Academic Centers

\begin{tabular}{|c|c|}
\hline Successors' internal barriers & External barriers \\
\hline $\begin{array}{l}\text { Personality-related: } \\
\text { - } \quad \text { Inability to accept change } \\
\text { - } \quad \text { Limited resistance to stress } \\
\text { Inclination to impose one's own will instead of } \\
\text { listening to others } \\
\text { - } \quad \text { Inexorability } \\
\text { - Lack of sensitivity to other people's needs } \\
\quad \text { Lack of openness }\end{array}$ & $\begin{array}{l}\text { Market conditions: } \\
\text { - } \quad \text { Competition from larger companies } \\
\text { - Not realizing the requirements of globalization }\end{array}$ \\
\hline $\begin{array}{l}\text { Level of knowledge: } \\
\bullet \quad \text { Experience } \\
\cdot \quad \text { Professionalism } \\
\end{array}$ & $\begin{array}{l}\text { Culture and values: } \\
\text { - The senior's approach and employees' attitude } \\
\text { - Maladjustment to work requirements after the freedom suc- } \\
\text { cessors had when growing up } \\
\text { - } \quad \text { Lack of knowledge about organizational culture } \\
\text { Questionable attitude to honesty }\end{array}$ \\
\hline $\begin{array}{l}\text { Competencies: } \\
\text { - } \quad \text { Problems with communication } \\
\text { - } \quad \text { Lack of ability to work in a group } \\
\quad \text { creativity and innovativeness }\end{array}$ & $\begin{array}{l}\text { Interpersonal relations: } \\
\text { - } \quad \text { Large number of successors } \\
\text { - } \quad \text { Distorted family relationships }\end{array}$ \\
\hline
\end{tabular}

Source: Authors' own data

Table 2. Classification of Identified Barriers in Succession Process from Successors' Perspective $(n=25)$

\begin{tabular}{l} 
Internal barriers \\
\hline Fears (encompassing several indications) \\
Lack of professional training \\
Lack of experience \\
Lack of practical experience \\
Other points of interest \\
Other plans (including reluctance to run a business) \\
Too young age
\end{tabular}

Source: Authors’ own data

\section{External barriers}

Bad relations with parents

The number of successors

Uncertainty

Unfamiliarity with the trade

Lack of perspectives for development of the firm

Lack of capital

Bureaucracy

Young age of the present owner 
firm; $X_{8}=$ fear of responsibility; $X_{9}=$ fear of being unsuccessful; $X_{10}=$ fear of criticism; $X_{11}=$ reluctance to run a business; $\mathrm{X}_{12}=$ lack of capital; $\mathrm{X}_{13}=$ large competition in the market; $X_{14}=$ uncertainty; $X_{15}=$ bureaucracy; $X_{16}=$ young age of the present owner; $X_{17}=$ lack of practical experience; $\mathrm{X}_{18}=$ other points of interest; and $\mathrm{X}_{19}=$ unfamiliarity with the trade. The questionnaire also included questions about the completed succession process $\left(\mathrm{X}_{0}\right)$ and whether the company possessed a business model $\left(\mathrm{X}_{21}\right)$. The responses to these questions were coded in a $0-1$ scale, where 0 meant "no" and 1 meant "yes." Moreover, the respondents were asked how they assessed the strategies implemented in their firm $\left(\mathrm{X}_{20}\right)$. They answered this question using a five-point Likert scale. The collation of results obtained in the conducted study is presented in Table 3.

The largest barrier, often paralyzing the successor in the succession process, is the fear of responsibility. Both the weighted means and the dispersion of results indicated that this barrier was the most challenging according to successors. The next two barriers, also related to successors' personality traits, were fear of criticism from parents, seniors, and firm employees and fear of competition, understood as the competition within the family and competition on the market. The obtained data allowed us to elaborate on the visualization of the profile of the successors' largest barriers in the succession process of Polish family firms, as illustrated in Figure 1.

\section{Research Methodology Using a Grey Incidence Analysis}

Due to the small sample, composed of the representatives of 25 family enterprises, the analysis of the results was conducted using a grey incidence analysis (Liu \& Yi, 2006; Mierzwiak \& Więcek-Janka, 2015). The main objective of

Table 3. Results of Empirical Study

\begin{tabular}{|c|c|c|c|c|c|c|c|c|c|c|c|c|c|c|c|c|c|c|c|c|c|}
\hline No. & $x_{0}$ & $x_{2}$ & $x_{3}$ & $X_{4}$ & $X_{5}$ & $x_{6}$ & $x_{7}$ & $X_{8}$ & $X_{9}$ & $x_{10}$ & $X_{11}$ & $X_{12}$ & $X_{13}$ & $X_{14}$ & $X_{15}$ & $X_{16}$ & $X_{17}$ & $X_{18}$ & $X_{19}$ & $x_{20}$ & $x_{21}$ \\
\hline 1 & 0 & 5 & 4 & 3 & 3 & 3 & 3 & 4 & 3 & 3 & 3 & 3 & 4 & 4 & 5 & 4 & 4 & 3 & 4 & 3 & 0 \\
\hline 2 & 0 & 4 & 4 & 4 & 4 & 4 & 5 & 4 & 4 & 4 & 3 & 5 & 4 & 4 & 5 & 4 & 4 & 3 & 4 & 1 & 0 \\
\hline 3 & 1 & 5 & 5 & 3 & 3 & 3 & 3 & 3 & 3 & 3 & 2 & 4 & 4 & 2 & 1 & 3 & 2 & 2 & 1 & 3 & 1 \\
\hline 4 & 0 & 4 & 3 & 3 & 3 & 4 & 4 & 5 & 3 & 3 & 5 & 4 & 4 & 4 & 3 & 3 & 4 & 3 & 2 & 2 & 0 \\
\hline 5 & 0 & 2 & 5 & 4 & 4 & 5 & 4 & 1 & 2 & 5 & 4 & 4 & 3 & 4 & 3 & 4 & 3 & 4 & 5 & 1 & 0 \\
\hline 6 & 1 & 3 & 2 & 2 & 2 & 2 & 3 & 2 & 2 & 2 & 3 & 3 & 3 & 3 & 3 & 4 & 3 & 1 & 3 & 3 & 1 \\
\hline 7 & 0 & 4 & 3 & 3 & 3 & 3 & 3 & 3 & 3 & 4 & 3 & 3 & 4 & 4 & 2 & 3 & 4 & 4 & 2 & 3 & 1 \\
\hline 8 & 0 & 5 & 5 & 3 & 3 & 4 & 4 & 3 & 3 & 3 & 3 & 3 & 4 & 4 & 4 & 3 & 4 & 3 & 2 & 3 & 0 \\
\hline 9 & 0 & 3 & 3 & 4 & 3 & 4 & 3 & 4 & 4 & 4 & 3 & 4 & 3 & 3 & 4 & 3 & 3 & 4 & 3 & 2 & 0 \\
\hline 10 & 1 & 2 & 3 & 3 & 3 & 1 & 1 & 3 & 3 & 2 & 2 & 1 & 3 & 3 & 3 & 3 & 4 & 3 & 1 & 3 & 1 \\
\hline 11 & 1 & 4 & 3 & 2 & 3 & 2 & 1 & 1 & 1 & 1 & 1 & 3 & 3 & 3 & 3 & 3 & 2 & 2 & 3 & 3 & 1 \\
\hline 12 & 0 & 5 & 4 & 5 & 3 & 3 & 5 & 5 & 5 & 5 & 5 & 3 & 3 & 3 & 5 & 3 & 5 & 5 & 3 & 1 & 0 \\
\hline 13 & 1 & 4 & 4 & 4 & 1 & 2 & 3 & 4 & 3 & 1 & 1 & 3 & 3 & 2 & 4 & 2 & 3 & 2 & 4 & 3 & 1 \\
\hline 14 & 0 & 5 & 4 & 5 & 3 & 3 & 3 & 3 & 4 & 3 & 3 & 3 & 5 & 5 & 5 & 4 & 4 & 3 & 3 & 1 & 0 \\
\hline 15 & 0 & 3 & 3 & 2 & 2 & 5 & 5 & 3 & 3 & 3 & 3 & 4 & 2 & 2 & 4 & 4 & 4 & 4 & 4 & 2 & 1 \\
\hline 16 & 0 & 3 & 3 & 3 & 3 & 3 & 3 & 3 & 3 & 3 & 4 & 4 & 4 & 3 & 5 & 4 & 4 & 4 & 3 & 2 & 1 \\
\hline 17 & 0 & 3 & 4 & 5 & 3 & 3 & 4 & 3 & 4 & 5 & 5 & 5 & 4 & 3 & 2 & 3 & 3 & 3 & 3 & 2 & 0 \\
\hline 18 & 1 & 2 & 3 & 3 & 4 & 3 & 2 & 3 & 3 & 4 & 3 & 3 & 3 & 3 & 3 & 3 & 3 & 1 & 1 & 3 & 1 \\
\hline 19 & 0 & 5 & 5 & 5 & 5 & 4 & 5 & 5 & 5 & 5 & 5 & 5 & 4 & 4 & 3 & 4 & 4 & 4 & 4 & 1 & 0 \\
\hline 20 & 0 & 5 & 4 & 4 & 4 & 4 & 4 & 3 & 3 & 3 & 3 & 4 & 4 & 5 & 3 & 4 & 4 & 4 & 3 & 1 & 0 \\
\hline 21 & 0 & 5 & 4 & 2 & 3 & 3 & 4 & 4 & 3 & 5 & 5 & 5 & 4 & 4 & 3 & 4 & 4 & 4 & 3 & 1 & 0 \\
\hline 22 & 0 & 4 & 3 & 3 & 3 & 3 & 4 & 4 & 3 & 3 & 3 & 3 & 4 & 3 & 3 & 3 & 4 & 2 & 3 & 2 & 1 \\
\hline 23 & 1 & 3 & 2 & 2 & 2 & 3 & 4 & 4 & 4 & 3 & 3 & 3 & 2 & 3 & 3 & 2 & 4 & 2 & 1 & 3 & 1 \\
\hline 24 & 1 & 3 & 3 & 3 & 3 & 3 & 3 & 3 & 4 & 4 & 4 & 4 & 3 & 3 & 3 & 3 & 3 & 3 & 2 & 3 & 1 \\
\hline 25 & 0 & 4 & 4 & 4 & 4 & 4 & 3 & 3 & 3 & 3 & 3 & 4 & 4 & 3 & 4 & 4 & 4 & 3 & 3 & 1 & 0 \\
\hline
\end{tabular}

Source: Authors' own data. 
Figure 1. Profile of barriers in succession process from the successor's point of view $(n=25)$.

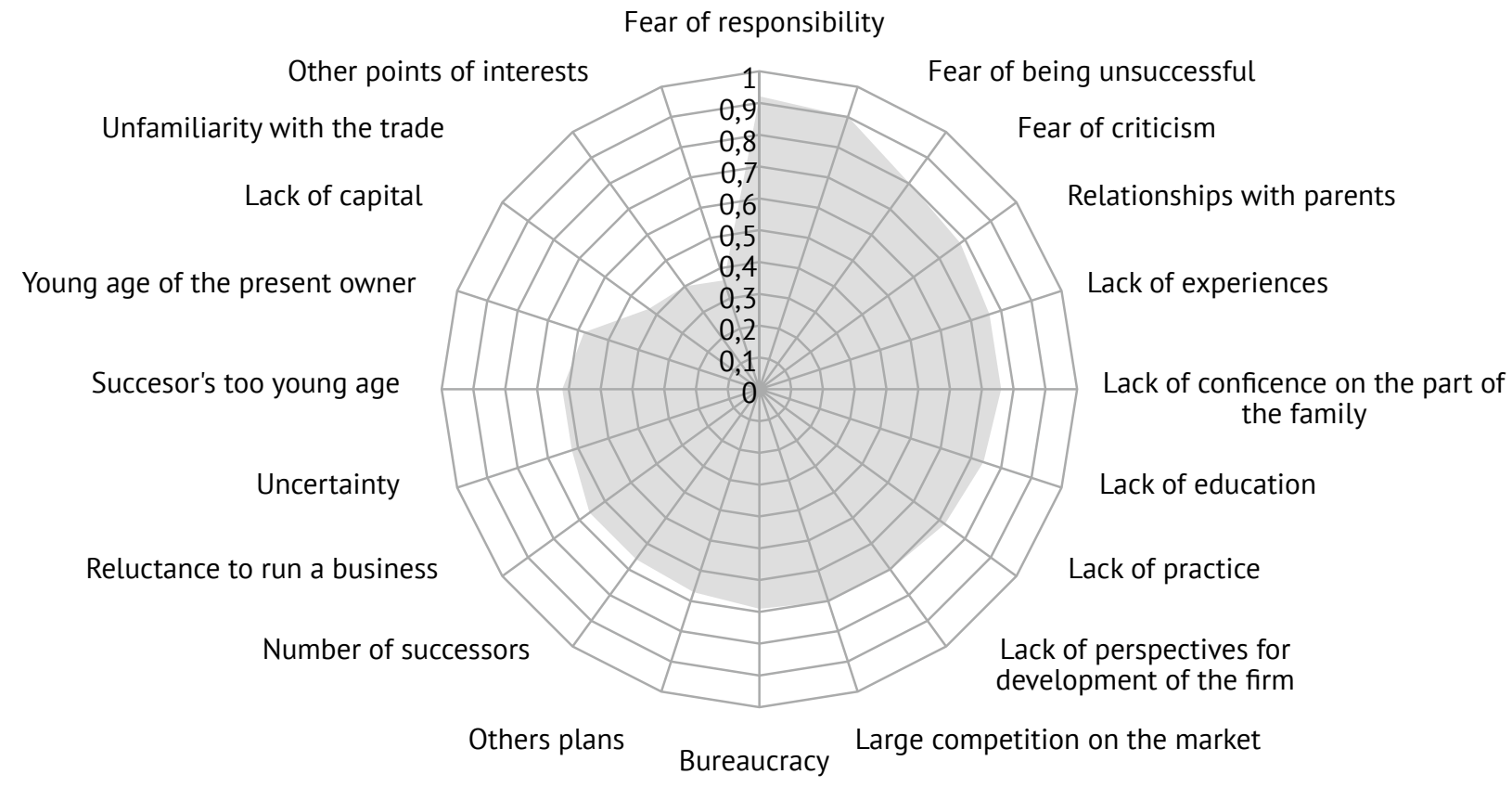

Results are expressed as the weighted means.

Source: Author's own data

employing this method was to discover the relationships between the identified barriers and undergoing the succession process by a firm, possessing the company's own business models and undergoing the succession process by a firm, as well as the assessment of strategy realisation and undergoing the succession process by a firm. (Więcek-Janka \& Mierzwiak, 2015, p 310).

In order to determine the influence of particular barriers on the succession process, the absolute degree of grey incidence process was applied in order to measure the correlation between the sequences ( $\mathrm{Liu} \& \mathrm{Yi}, 2006$ ).

Assuming that $\mathrm{X}_{0}$ is a description of the surveyed enterprise system and that the relevant factors are $\mathrm{X}_{1}-\mathrm{X}_{19}$, the calculation is as follows (Liu \& Yi, 2006):

\section{Computing zero starting point images of $X_{0}$ and $X_{i}$}

$X_{i} D=\left(x_{i}(1) d, x_{i}(2) d, \ldots, x_{i}(n) d\right), k=1,2, \ldots, 25$

$x_{i}(k) d=x_{i}(k)-x_{i}(1)$

$\mathrm{X}_{0}^{\prime}(0,0,1,0,0,1,0,0,0,1,1,0,1,0,0,0,0,1,0,0,0,0,1,1,0)$

$\mathrm{X}_{1}^{\prime}(0,0,2,0,1,0,0,0,0,-1,2,2,1,2,-2,0,0,0,1,1,0,1,0,0,2)$

$\mathrm{X}_{2}^{\prime}(0,-1,0,-1,-3,-2,-1,0,-2,-3,-1,0,-1,0,-2,-2,-2,-3,0,0,0,-1,-2,-2,-1)$

$X_{3}^{\prime}(0,0,1,-1,1,-2,-1,1,-1,-1,-1,0,0,0,-1,-1,0,-1,1,0,0,-1,-2,-1,0)$

$\mathrm{X}_{4}^{\prime}(0,1,0,0,1,-1,0,0,1,0,-1,2,1,2,-1,0,2,0,2,1,-1,0,-1,0,1)$

$X_{5}^{\prime}(0,1,0,0,1,-1,0,0,0,0,0,0,-2,0,-1,0,0,1,2,1,0,0,-1,0,1)$
$\mathrm{X}_{6}^{\prime}(0,1,0,1,2,-1,0,1,1,-2,-1,0,-1,0,2,0,0,0,1,1,0,0,0,0,1)$

$\mathrm{X}_{7}^{\prime}(0,2,0,1,1,0,0,1,0,-2,-2,2,0,0,2,0,1,-1,2,1,1,1,1,0,0)$

$X_{8}^{\prime}(0,0,-1,1,-3,-2,-1,-1,0,-1,-3,1,0,-1,-1,-1,-1,-1,1,-1,0,0,0,-1,-1)$

$\mathrm{X}_{9}^{\prime}(0,1,0,0,-1,-1,0,0,1,0,-2,2,0,1,0,0,1,0,2,0,0,0,1,1,0)$

$\mathrm{X}_{10}^{\prime}(0,1,0,0,2,-1,1,0,1,-1,-2,2,-2,0,0,0,2,1,2,0,2,0,0,1,0)$

$\mathrm{X}_{11}^{\prime}(0,0,-1,2,1,0,0,0,0,-1,-2,2,-2,0,0,1,2,0,2,0,2,0,0,1,0)$

$\mathrm{X}_{12}^{\prime}(0,2,1,1,1,0,0,0,1,-2,0,0,0,0,1,1,2,0,2,1,2,0,0,1,1)$

$\mathrm{X}_{13}^{\prime}(0,0,0,0,-1,-1,0,0,-1,-1,-1,-1,-1,1,-2,0,0,-1,0,0,0,0,-2,-1,0)$

$X_{14}^{\prime}(0,0,-2,0,0,-1,0,0,-1,-1,-1,-1,-2,1,-2,-1,-1,-1,0,1,0,-1,-1,-1,-1)$

$X_{15}^{\prime}(0,0,-4,-2,-2,-2,-3,-1,-1,-2,-2,0,-1,0,-1,0,-3,-2,-2,-2,-2,-2,-2,-2,-1)$

$X_{16}^{\prime}(0,0,-1,-1,0,0,-1,-1,-1,-1,-1,-1,-2,0,0,0,-1,-1,0,0,0,-1,-2,-1,0)$

$X_{17}^{\prime}(0,0,-2,0,-1,-1,0,0,-1,0,-2,1,-1,0,0,0,-1,-1,0,0,0,0,0,-1,0)$

$\mathrm{X}_{18}^{\prime}(0,0,-1,0,1,-2,1,0,1,0,-1,2,-1,0,1,1,0,-2,1,1,1,-1,-1,0,0)$

$X_{19}^{\prime}(0,0,-3,-2,1,-1,-2,-2,-1,-3,-1,-1,0,-1,0,-1,-1,-3,0,-1,-1,-1,-3,-2,-1)$

\section{Calculating}

$\left|s_{0}\right|,\left|s_{1}\right|,\left|s_{2}\right|, \ldots,\left|s_{19}\right|,\left|s_{1}-s_{0}\right|,\left|s_{2}-s_{0}\right|,\left|s_{3}-s_{0}\right|, \ldots,\left|s_{19}-s_{0}\right|$.

$\left|s_{i}\right|=\left|\sum_{k=2}^{n-1} x_{i}^{0}(k)+\frac{1}{2} x_{i}^{0}(n)\right|$

$\left|s_{j}\right|=\left|\sum_{k=2}^{n-1} x_{j}^{0}(k)+\frac{1}{2} x_{j}^{0}(n)\right|$,

$\left|s_{i}-s_{j}\right|=\left|\sum_{k=2}^{n-1}\left[x_{i}^{0}(k)-x_{j}^{0}(k)\right]+\frac{1}{2}\left[x_{i}^{0}(n)-x_{j}^{0}(n)\right]\right|$. 
$\left|s_{0}\right|=8,\left|s_{1}\right|=11,\left|s_{2}\right|=29,5,\left|s_{3}\right|=10,\left|s_{4}\right|=8,5,\left|s_{5}\right|=1,5,\left|s_{6}\right|=5,5,\left|s_{7}\right|=11$,

$\left|s_{8}\right|=16,5,\left|s_{9}\right|=6,\left|s_{10}\right|=9,\left|s_{11}\right|=7,\left|s_{12}\right|=14,5,\left|s_{13}\right|=12,\left|s_{14}\right|=15,5$,

$\left|s_{15}\right|=38,5,\left|s_{16}\right|=16,\left|s_{17}\right|=10,\left|s_{18}\right|=1,\left|s_{19}\right|=29,5$.

$\left|s_{1}-s_{0}\right|=3,\left|s_{2}-s_{0}\right|=37,5,\left|s_{3}-s_{0}\right|=18,\left|s_{4}-s_{0}\right|=0,5$,

$\left|s_{5}-s_{0}\right|=6,5,\left|s_{6}-s_{0}\right|=2,5,\left|s_{7}-s_{0}\right|=3,\left|s_{8}-s_{0}\right|=24,5$,

$\left|s_{9}-s_{0}\right|=2,\left|s_{10}-s_{0}\right|=1,\left|s_{11}-s_{0}\right|=1,\left|s_{12}-s_{0}\right|=6,5$,

$\left|s_{13}-s_{0}\right|=20,\left|s_{14}-s_{0}\right|=23,5,\left|s_{15}-s_{0}\right|=46,5,\left|s_{16}-s_{0}\right|=24$,

$\left|s_{17}-s_{0}\right|=18,\left|s_{18}-s_{0}\right|=7,\left|s_{19}-s_{0}\right|=37,5$.

\section{Computing the absolute degree of grey incidence}

$\varepsilon_{i j}=\frac{1+\left|s_{i}\right|+\left|s_{j}\right|}{1+\left|s_{i}\right|+\left|s_{j}\right|+\left|s_{j}-s_{i}\right|}$

$\varepsilon_{01}=0,87 ; \varepsilon_{02}=0,507 ; \varepsilon_{03}=0,514 ; \varepsilon_{04}=0,972 ; \varepsilon_{05}=0,618 ; \varepsilon_{06}=0,853$;

$\varepsilon_{07}=0,87 ; \varepsilon_{08}=0,51 \quad \varepsilon_{09}=0,882 ; \varepsilon_{0,10}=0,947 ; \varepsilon_{0,11}=0,941 ; \varepsilon_{0,12}=0,783$;

$\varepsilon_{0,13}=0,512 ; \varepsilon_{0,14}=0,51 ; \varepsilon_{0,15}=0,505 ; \varepsilon_{0,16}=0,51 \varepsilon_{0,17}=0,514$;

$\varepsilon_{0,18}=0,588 ; \varepsilon_{0,19}=0,507$

Based on the absolute degree of grey incidence coefficient, we identified the following arrangement of the influence of the barriers on succession process: $\mathrm{X}_{4}$ (other plans) $>\mathrm{X}_{10}$ (fear of criticism) $>X_{11}$ (reluctance to run a business) $>$ $\mathrm{X}_{9}$ (fear of being unsuccessful) $>\mathrm{X}_{1}$ (lack of professional training) $>X_{7}$ (lack of perspectives for development of the firm) $>X_{6}$ (large number of successors) $>X_{12}$ (lack of capital) $>\mathrm{X}_{5}$ (successor is too young) $>\mathrm{X}_{18}$ (other points of interest) $>X_{3}$ (bad relationships with parents) $>X_{17}$ (lack of practical experience) $>X_{13}$ (large competition on the market) $>\mathrm{X}_{14}$ (uncertainty) $>\mathrm{X}_{16}$ (young age of the present owner) $>X_{8}$ (fear of responsibility) $>X_{2}$ (lack of experience) $>X_{19}$ (unfamiliarity with the trade) $>\mathrm{X}_{15}$ (bureaucracy).

In order to determine the relationship among the company's business models $\left(\mathrm{X}_{21}\right)$, the assessment of strategy realization $\left(\mathrm{X}_{20}\right)$, and the company's succession process, the absolute degree of grey incidence method was employed again, resulting in the following calculations:

\section{Computing zero starting point images of $X_{0}, X_{20}$, and $\mathrm{X}_{21}$ based on formula (1)}

$\mathrm{X}_{0}(0,0,1,0,0,1,1,0,0,1,1,0,1,0,1,1,0,1,0,0,0,1,1,1,0)$

$X_{20}(0,-2,0,-1,-2,0,0,0,-1,0,0,-2,0,-2,-1,-1,-1,0,-2,-2,-2,-1,0,0,-2)$

$\mathrm{X}_{21}(0,0,1,0,0,1,0,0,0,1,1,0,1,0,0,0,0,1,0,0,0,0,1,1,0)$

2. Calculating $\left|s_{0}\right|,\left|s_{20}\right|,\left|s_{21}\right|,\left|s_{20}-s_{0}\right|,\left|s_{21}-s_{0}\right|$ based on formula (2)

$$
\begin{aligned}
& \left|s_{0}\right|=8,\left|s_{20}\right|=21,\left|s_{21}\right|=12 . \\
& \left|s_{20}-s_{0}\right|=29,\left|s_{21}-s_{0}\right|=4 .
\end{aligned}
$$

\section{Computing the absolute degree of grey incidence based on formula (3)}

$\varepsilon_{0,20}=0,508 ; \varepsilon_{0,21}=0,84 \Rightarrow$

$\mathrm{X}_{21}$ (there is a business model) $>\mathrm{X}_{20}$ (strategic planning)

The absolute degree of grey incidence indicated the relationship between the system's factors $\left(\mathrm{X}_{21}, \mathrm{X}_{22}\right)$ and characteristics $\left(\mathrm{X}_{0}\right)$. The relationship was assessed using the geometric similarities of its sequences. The higher the value of the absolute degree of grey incidence, where the lowest value of the relative relational degree is 0.5 (Xie \& Liu, 2009), the higher the similarity between the system's factors and characteristics is. Therefore, having a company's own business model $\left(\mathrm{X}_{21}\right)$ is related more to the ongoing succession when compared to the strategy realization $\left(\mathrm{X}_{20}\right)$.

\section{Conclusions}

The obtained material allowed the researchers to verify the elaborated provisional model, which has been considerably changed as a result of the conducted analysis. The results of the study indicated a distinct arrangement of the barriers influencing the succession process in the opinion of the successors in Polish family firms. Barrier $\mathrm{X}_{4}$ (other plans) ought to be considered the most significant barrier after the verification of the model, as the value of absolute degree of grey incidence equaled 0.972 . The obtained result is close to the result obtained for the succession process. Enterprises in which this barrier received the highest rating have not undergone the succession process thus far.

The next significant barrier was $\mathrm{X}_{10}$ (fear of criticism) with a value of 0.947. Successors assessed this barrier similarly to $\mathrm{X}_{4}$, and the explanation of such behavior of variables can be the thesis that this barrier is primordial to the previously discussed one. It might be shaped in the process of upbringing and socialization, even it successors' early years. Fear of criticism might be built into the individual value system, and the idiosyncratic defense mechanism of a particular personality reacted with transference (Valliant, 2005). Due to such a mechanism, a more objective barrier emerged-namely, the socially accepted other plans. Another barrier might be shaped on the basis of the same mechanism and is related to the declared reluctance to run a business $\left(\mathrm{X}_{11}\right)$, with an equally high absolute degree of grey incidence amounting to 0.941 . Other barriers distinguished and highly correlated to undergoing the succession process belong to the group 
of primordial barriers shaped over the years of socialization and formation (or rather their absence) of social and entrepreneurial competencies. They encompass $X_{9}$ (fear of being unsuccessful) with the result of $0.882, \mathrm{X}_{1}$ (perceived lack of professional training) with the result of 0.870 , and $\mathrm{X}_{7}$ (lack of perspectives for development of the firm) with exactly the same result.

The barriers indicated and verified according to the presented methodology also suggested the capability to assess one's condition leading to self-complacency. The respondents' assessments of the barriers in the succession process might have been drawn from their so-called pre-understanding, which is created from previous experiences and often shaped in early childhood (Anderson \& Goolishian, 1992).

The employed methodology of the absolute degree of grey incidence enabled us to develop a final version of the model of successors' barriers in the course of the succession process in Polish family firms (see Figure 2).

Figure 2. Profile of barriers in succession process from successor's point of view $(n=25)$

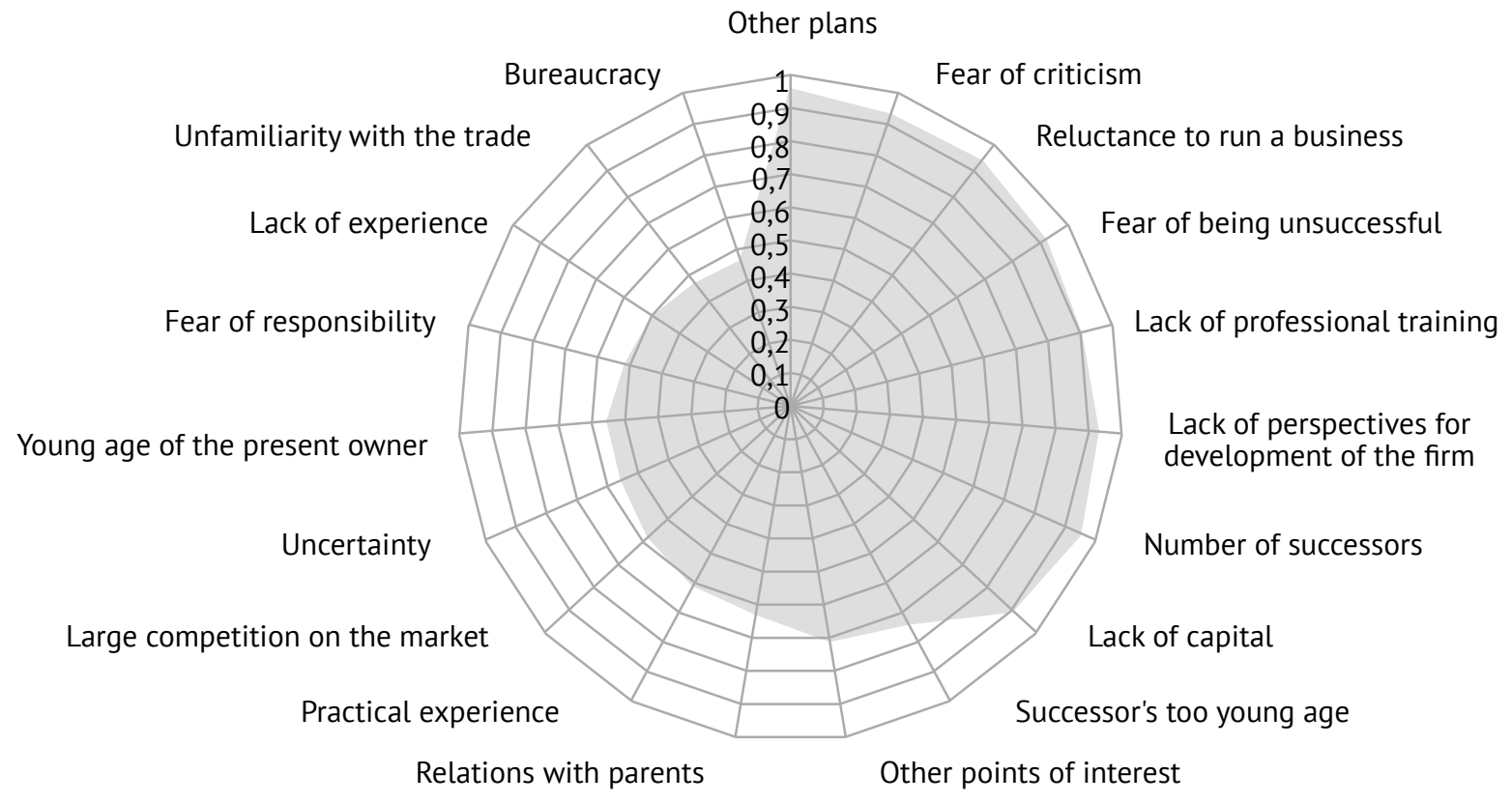

Source: Author’s own data

own competencies as a successor ${ }^{1}$ and knowledge of market conditions of family business functioning. The number of successors $\left(\mathrm{X}_{6}\right)$ with the result amounting to 0.870 has an equally large influence on the positive course of succession. The remaining identified barriers in the succession process did not receive such considerable results from the absolute degree of grey incidence analysis, indicating that their relation to the course of succession process is not as close.

The original view obtained on the classification of barriers in the Polish succession process did not considerably diverge from the psychodynamic approach, which explains that people have a natural tendency to maintain an equilibrium of the mind and actions and make their decisions rationally. Moreover, the human psyche strives to drift away from the imbalanced state, leaving negative and often chaotic scenarios and thoughts, and attempts to reach a more stable
The conducted study identified, for the first time in Poland, considerable deficiencies in the research carried out thus far. The obtained profile of statistical successors' barriers corroborated that the barriers to the succession of Polish successors can result from the inappropriate preparation of the younger generation to taking over the business. Hence, one can put forward a hypothesis, to be corroborated in further research, that the upbringing process lacks the ideas for shaping entrepreneurial competencies, which might be helpful in overcoming the fears that the successors have to face when taking over family firms.

\footnotetext{
1 As presented in other studies by the research team.
} 


\section{References}

1. Aldrich, H., \& Cliff J. (2003). The pervasive effects of family on entrepreneurship, toward a family embeddedness perspective. Journal of Business Venturing, 12, 573-596. http://dx.doi.org/10.1016/S0883-9026(03)00011-9

2. Anderson, H., \& Goolishian, H. (1992). The client is the expert: A not-knowing approach to therapy. In S. McNamee \& K. Gergen (Eds.), Social construction and the therapeutic process. Newbury Park, CA: Sage.

3. Arnoff, C. E., McClure, S. L., \& Ward, J. L. (2012). Succession in family businesses (Sukcesja w firmach rodzinnych). Kraków: MiP Publishing House.

4. Astrachan, J. H., \& Kolenko, T. A. (1994). A neglected factor explaining family business success: Human resource practices. Family Business Review, 7(3), 251-262. http://dx.doi.org/10.1111/j.1741-6248.1994.00251.x

5. Astrachan, J. H., \& Shanker, M. C. (2003). Family businesses' contribution to the U.S. economy: A closer look. Family Business Review, 16(3), 211-219.

6. Barach, J. A., \& Ganitsky, J. B. (1995). Successful succession in family business. Family Business Review, 8(2), 131-155. http://dx.doi.org/10.1111/j.1741-6248.1995.00131.x

7. Barnes, L. B. (1988). Incongruent hierarchies: Daughters and younger sons as company CEOs. Family Business Review, 1, 9-21. http://dx.doi.org/10.1111/j.1741-6248.1988.00009.x

8. Blake, C. G., \& Saleh, D. D. (1995). A model of family owned small business performance. Family Business Annual, 1, 22 -30.

9. Budge, G. S., \& Janoff, R. F. (1991). Succession in women-owned family businesses: A case study. Family Business Review, 4(4), 367-381. http://dx.doi.org/10.1111/j.1741-6248.1991.00367.x

10. Cadieux, L., Lorrain, J., \& Hugron, P. (2002). Succession in women owned family businesses: A case study. Family Business Review, 15, 17-30. http://dx.doi.org/10.1111/j.1741-6248.2002.00017.x

11. Danco, L. (1975). Beyond survival-A business owner's guide for success. Cleveland, OH: University Press.

12. Davis, J. A. (1982). The influence of life stage on father-son relationships in the family firm (Doctoral dissertation). Harvard Business School.

13. Duh, M. (2003). Family business. Development in strategy management family business (Druzinsko podjetje. Razvoj in razvojni management druzinskego podjetia). MER Evrocenter, Maribor: Publishing House MER.

14. Duh, M., Belak, J., \& Milfelner, B. (2010). Core values, culture and ethical climate as constitutional elements of ethical behaviour: Exploring differences between family and non-family enterprises.Journal of Business Ethics, 97, 473-489. http://dx.doi.org/10.1007/ s10551-010-0519-9

15. Dunk, A., Jimenez, P., Sarotar Zizek, S., Milfelner B., \& Kallus, W. K. (2015). Similarities and differences of health-promoting leadership and transformational leadership. Our Economy, 61(4), 3-13.

16. Dyer, G. W. (2006). Examining the "family effect" on firm performance. Family Business Review, 19(4), 253-273. http://dx.doi. org/10.1111/j.1741-6248.2006.00074.x

17. Dyer, W. G. (2003). The family, the missing variable in organizational research. Entrepreneurship. Theory and Practice, 27(4), $401-416$. http://dx.doi.org/10.1111/1540-8520.00018

18. Ganitsky, J. A., Carson, J. B., \& Doochin, B. A. (1988). Entry of the next generation: Strategic challenge for family business. Journal of Small Business Management, 26, 49-56.

19. Handler, W. C., \& Kram, K. E. (1989). Succession in family firms: The problem of resistance. Family Business Review, 1, $361-381$. http://dx.doi.org/10.1111/j.1741-6248.1988.00361.x

20. Kedmenec, I., Sebjan, U., \& Tomic, P. (2015). Effect of rurality and human capital resources in the entrepreneurial opportunity identification process. Our Economy, 61(2), 35-44.

21. Kepner, E. (1991). The family and the firm: A coevolutionary perspective. Family Business Review, 4, 445-461. http://dx.doi. org/10.1111/j.1741-6248.1991.00445.x

22. Klien, S. B. (2000). Family businesses in Germany, Significance and structure. Family Business Review, 6, 769-784. http://dx.doi. org/10.1111/j.1741-6248.2000.00157.x

23. Lansberg, I. (1988). The succession conspiracy. Family Business Review, 1, 119-143. http://dx.doi.org/10.1111/j.17416248.1988.00119.x

24. Letonja, M., \& Duh, M. (2015). Knowledge transfer in family businesses and its effects on the innovativeness of the next family generation. Knowledge Management Research \& Practice, December, 1-12. http://dx.doi.org/10.1057/kmrp.2015.25

25. Litz, R. A. (1995). The family business: Toward definitional clarity. Proceedings of the Academy of Management, 100-104. http://dx.doi. org/10.5465/AMBPP.1995.17536337

26. Liu, S., \& Yi, L. (2006). Grey information: theory and practical applications. New York: Springer Science \& Business Media.

27. Mierzwiak, R., \& Więcek-Janka, E. (2015). The analysis of successors' competencies in family enterprises with the use of grey system theory. Grey Systems: Theory and Application, 5(3), 302-312. http://dx.doi.org/10.1108/GS-03-2015-0007

28. Sharma, P. (2002, August). Stakeholder mapping technique: Toward the development of a family firm typology. Paper presented at the 62 nd meeting of the Academy of Management, Denver, CO.

29. Swagger, G. (1991). Assessing the successor generation in family businesses. Family Business Review, 4, 397-411. http://dx.doi. org/10.1111/j.1741-6248.1991.00397.x 
30. Ward, J. L. (1987). Keeping the family business healthy, San Francisco: Jossey-Bass.

31. Więcek-Janka, E. (2011). Games and decisions. Poznan: University of Technology Publishing House.

32. Więcek-Janka, E. (2013). The guiding value in the management of family businesses (Wiodące wartości w zarządzaniu przedsiębiorstwami rodzinnymi). Poznan: University of Technology Publishing House.

33. Więcek-Janka, E., Mierzwiak, R. (2015). The analisis of successors' competencies in family enterprises with the use of grey system theory. Grey Systems: Theory and Application, 5 ( 3), 302-312.

34. Vaillant G.E., (2005), Ego Mechanisms of Defense: A Guide for Clinicans and Researchers, American Psychiatic Press, Inc. Washington.

35. Xie, N., \& Liu, S. (2009). Research on evaluations of several grey relational models adapt to grey relational axioms. Journal of Systems Engineering and Electronics, 20(2), 304-309.

\section{Authors}

Ewa Więcek-Janka, Doctor of economics, MA in psychology, engineer of management, works at the Faculty of Engineering Management Poznan University of Technology, Marketing and Economic Engineering Department. She is a member of the Family Business Initiative, Association of Polish Engineers and Mechanics. She is the author of 98 publications, including books on applied management tools. She has participated in conferences abroad (Denmark, Sweden, Slovenia, USA, Italy) and has conducted in internship research and teaching in Finland, Mexico, Bulgaria, Romania, Hungary, Serbia, Slovenia, and Slovakia.

Joanna Kijewska, Ph.D. candidate in the Marketing and Economic Engineering Department at Poznan University of Technology, is completing her Ph.D. thesis on quality management of the integrated marketing communication. Her research interests center on the science of the quality, principles of marketing, and marketing management, especially the environmental scanning and quality of the marketing information system.

Rafał Mierzwiak, Ph.D., focuses on research into applications of grey systems theory in management. In this area, his most important efforts are his publications in scientific magazines, such as Journal of Cleaner Production, Lecture Notes of Computer Science, and Grey Systems: Theory and Application. He received prizes for the best paper at the international conferences in Cracow and Leicester.

\section{Analiza ovir v procesih nasledstva družinskih podjetjih z uporabo sive incidenčne analize (poljska perspektiva)}

\section{Izvleček}

v prispevku predstavljamo izide raziskave o zaznavanju in ocenjevanju ovir, s katerimi se srečujejo nasledniki v družinskih podjetjih v prvem procesu nasledstva.V empirični analizi smo uporabili sivo sistemsko teorijo, ki smo jo ocenili kot enakovredno za analizo majhnih vzorcev in kvalitativno raziskavo. Pri pregledu literature in v empirični raziskavi smo se osredotočili na: a) identifikacijo ovir pri razvoju družinskih podjetij ter b) opredeljevanje perspektive nove generacije lastnikov $v$ družinskih podjetjih, ki vstopajo $v$ proces nasledstva, z empirično analizo ocenjene ravni tveganja v povezavi z družino in poslom.

Ključne besede: družinsko podjetje, siva incidenčna analiza, siva sistemska teorija 